\title{
HOW DOES CREDIT RISK INFLUENCE LIQUIDITY RISK? EVIDENCE FROM UKRAINIAN BANKS
}

\author{
Ruoyu Cai \\ Management School, University of Sheffield, UK \\ Mao Zhang \\ Management School, University of Sheffield, UK \\ Corresponding author. Email: mzhang32@sheffield.ac.uk
}

\section{ABSTRACT}

This study investigates the link between two major risks in the banking sector: liquidity risk and credit risk. Utilizing a novel sample of Ukrainian banks for the period from Q1 2009 to Q4 2015, we document credit risk as having a positive relationship with liquidity risk. Our findings suggest banks with high level of non-performing loans might not meet depositors' withdrawal demands, which could lower cash flow and trigger depreciations in loan assets, and consequently increase liquidity risk. Furthermore, we find this positive relationship between credit risk and liquidity risk is more pronounced in foreign banks and large banks. Our results are robust with respect to alternative measures of bank risks.

\section{JEL Codes: G21, G31, G33}

Keywords: liquidity risk, credit risk, bank size, bank ownership

\section{INTRODUCTION}

The collapse in 2008 of Lehman Brothers, a global bank, brought down the global financial system, triggering numerous bank failures. In the wake of the crisis, substantial bailouts were required to shore up the financial sector. Anecdotal evidence suggests most bank failures are partly caused by liquidity problems and by the credit crunch. For example, the Material Loss Reports from the Federal Deposit Insurance Corporation (FDIC) state that liquidity risk and credit risk together contributed to most commercial bank failures during the recent crisis. ${ }^{1}$

In the banking sector, liquidity risk and credit risk are considered the major sources of default risk. Liquidity is viewed as a fundamental part of banking operations (Cornett et al., 2011) and the Basel Committee on Banking Supervision defines liquidity risk as the risk of being unable to meet the obligations of depositors or to fund increases in assets, which stems from a shortage of liquid assets (2008). Credit is another important element in banking. Credit risk materializes when a bank borrower or counterparty fails to meet obligations per agreed terms (Casu et al., 2006). Additionally, since banks accept deposits from savers and lend those funds to borrowers, a bank's asset and liability structures are closely connected, especially in terms of borrower defaults and deposit outflows (Bryant, 1980). Thus: are liquidity risk and credit risk closely related in banks?

A large amount of literature has investigated liquidity risk and credit risk in banks (e.g., Berger and Bouwman, 2009; Castro, 2013; Diamond and Rajan, 2001). The literature contains two main views on the link between the two risks. The first, the classic financial intermediation theory (Bryant, 1980) and the Diamond and Dybvig (1983) model, suggests liquidity risk and credit risk are positively related in banks, which is supported by empirical studies (e.g., Acharya and Viswanathan, 2011; Gorton and Metrick, 2011; He and Xiong, 2012). More specifically, a loan default can increase liquidity risk by leading to a decrease in cash flow and depreciations in loan assets (Dermine, 1986). For example, if a bank lends to distressed projects, it may then struggle to meet depositors' demands for funds. Then, if asset values deteriorate, depositors may demand their funds. On the other hand, some empirical studies also document a negative relation or no relation at all between liquidity risk and credit risk (e.g., Cai and Thakor, 2008; Wagner, 2007). These studies share a common trait - they focus on specific features of credit risk or liquidity risk, or on/ narrow economic circumstances. Given the contradictory viewpoints presented in the literature, the relationship between credit risk and liquidity risk remains an open question.

${ }^{1}$ The FDIC publishes Material Loss Reports for all bank defaults that result in a "material loss" to the FDIC insurance fund. 
Ukraine, an emerging market, offers an interesting framework in which to study the relationship between credit risk and liquidity risk. In the face of the political and economic challenges in recent years, Ukraine is viewed as a struggling economy and its banking sector has been named as one of the least efficient and highest cost emerging markets (Fries and Taci, 2005). Based on the Banking Industry Country Risk Assessment (2017) released by S\&P Global, the risk in the Ukrainian banking system remains one of the highest in a global comparison due to the country's unstable political and economic environments. During the global financial crisis in 2008, Ukrainian banks experienced a sharp downturn and regional and sectoral imbalances (Liubkina and Borovikova, 2013), with outflows of deposits, a decreased liquidity position, and the threat of default risk. Rising non-performing loans (NPLs) also forced banks' profitability into losses. To relieve the pressure in the banking sector, the National Bank of Ukraine (NBU) introduced a large package of liquidity support.

In 2010, the economy began to recover from the serious recession; confidence in the banking sector returned and deposits returned to growth. After a short recovery, Ukrainian banks began to again accumulate the large imbalances until 2014-2015 when conditions deteriorated. Total deposits decreased 15\% in 2014 and returned to growth only in the middle of 2015 as confidence in banks returned. Meanwhile, bad loans surged from 4.6\% of all loans at the start of 2014 to $24.3 \%$ in late 2014 (Barisitz et al., 2012; Barisitz and Fungáčová, 2015). More recently, as reported in the Financial Stability Report (NBU, 2016), NPLs remain at record highs, while the late recognition of regulation contributes to the minor increase in the bad loans. Furthermore, liquidity risk has not abated because the distribution of high-quality liquid assets in Ukrainian banks is uneven. Overall, Ukrainian banks continue to face high levels of credit risk and liquidity risk.

To study the relationship between liquidity risk and credit risk in the Ukrainian banking sector, we use a novel sample of 176 Ukrainian banks from Q1 2009 to Q4 2015. The data were collected from Ukrainian banks' quarterly reports from the NBU website. In terms of the methodology, we use the fixed-effects estimator, justified using the Hausman Test. Using the fixedeffects model enables us to control for unobserved heterogeneity. With respect to the results, we find a positive and significant impact of credit risk on liquidity risk in Ukrainian banks. The results show that when credit risk increases by 1 percentage point (pp), liquidity drops by $0.061 \mathrm{pp}^{2}$ A lower value of liquidity indicates a higher liquidity risk, meaning our results suggest that higher credit risk leads to higher liquidity risk in Ukrainian banks. In other words, a default in loans could easily increase the liquidity problem. Our main results are in-line with the classic financial intermediary theory (Bryant, 1980) and the Diamond and Dybvig (1983) model, as well as available empirical literature (e.g., Bryant, 1980; Dermine, 1986; Nikomaram et al., 2013).

Furthermore, since banks with different characteristics behave differently in terms of risk, we divide the banks into different sub-groups based on size and ownership. Our further estimation shows the positive relationship between credit risk and liquidity risk varies across different bank sizes and ownership types. We observe that the positive effect of credit risk is likely to exist only in larger, foreign owned banks. For foreign-owned banks, when credit risk increases 1 pp, liquidity falls 0.11 .8 pp. For large banks, a $1 \mathrm{pp}$ increase in credit risk results in an $0.084 \mathrm{pp}$ decrease in liquidity. Our results are robust with respect to alternative measures of bank risks.

Our study contributes to the existing literature on bank liquidity risk and credit risk. Most of the existing literature focuses on investigating these two major bank risks separately, while limited studies estimate the link between the two together (e.g., Berger and Bouwman, 2009; Foos et al., 2010; Houston et al., 2010; Imbierowicz, 2014; Laeven and Levine, 2009). Furthermore, most empirical studies on the relationship between liquidity risk and credit risk only focus on developed countries. To bridge the gap, we extend the literature to an emerging economy, Ukraine. To the best of our knowledge, this is the first study that estimates the relationship between liquidity risk and credit risk in Ukrainian banks.

The rest of the paper is organized as follows: section 2 presents a critical review of literature on liquidity risk and credit risk; section 3 describes the data collection and methodology; section 4 provides the empirical analysis; section 5 contains a series of robustness tests; section 6 contains the summary and conclusion.

\section{LITERATURE REVIEW AND DEVELOPMENT OF HYPOTHESIS}

\subsection{Bank liquidity risk}

The financial crisis proved that liquidity, an important factor in the banking sector, has the potential to influence banks' survival (DeYoung et al., 2016). Financial intermediation theories posit liquidity production as a key to banking operations (Cornett et al., 2011). In banks, liquid assets refer to cash and assets that can be converted to cash quickly with limited or no losses (Casu et al., 2006). Liquidity risk refers to the risk of being unable to meet the obligations of depositors or to fund increases in assets as they fall due without incurring unacceptable costs or losses (BCBS, 2008).

The opaque nature of banks, with high information asymmetry, may increase liquidity risk. If external stakeholders were to receive the same information on the quality of the portfolio as insiders, banks would provide an appropriate price to take in deposits and take portfolio risks (Greenbaum and Thakor, 1995). When depositors are in greater need of withdrawals

${ }^{2}$ In our study, we follow Cornett et al. (2011) to use liquidity (the change in the liquidity position) as a proxy for liquidity risk. Thus, a higher value of liquidity indicates a lower level of liquidity risk. 
than normal, liquidity risks can occur. To reduce the risk, banks can borrow funds from other banks or from the central bank. However, banks then pay a higher interest rate than the rate at which other banks borrow, which may increase the bank's costs. Banks can also reduce liquidity risk by increasing cash or other liquid assets, such as Treasury bills. This improves the bank's ability to sell assets, which can increase its resilience to liquidity shocks and diversify balance sheet risk (Cornett et al., 2011). Banks are therefore required to meet minimum liquidity standards according to the Basel III Accord (2010). However, holding more liquid assets carries associated costs. Holding too much cash can reduce profit because of the low returns of liquid assets (Casu et al., 2006).

Banks' asset and liability structures are closely connected, especially in terms of borrower defaults and deposit outflows (Bryant, 1980). Thus, a bank needs to identify and manage imbalances between assets and liabilities. Loans become illiquid assets when a bank provides liquid assets to borrowers (Diamond and Rajan, 2001), while loans can be used as collateral when banks need liquidity (Bhattacharya and Thakor, 1993). If demand for liquidity is high, banks can limit the supply of credit and change illiquid assets to liquid liabilities (Berger and Bouwman, 2009). However, banks can also create the liquidity by changing the funding on their liability side (Gorton and Winton, 2000). In addition, when borrowers choose to withdraw commitments, an off-balance sheet loan comes onto the balance sheet. In this case, half of commercial banks' liquidity creation occurs through off-balance sheet commitments (Berger and Bouwman, 2013).

\subsection{Bank credit risk}

Credit risk is another major element of bank default risk. The Basel Committee on Banking Supervision (2000) defines credit risk as the potential that a bank borrower or counterparty fails to meet its obligations in accordance with agreed terms. In other words, credit risk materializes when a loan is not paid in part or in full to a lender (Castro, 2013). Credit risk management is essential in identifying warning signs of a bank's vulnerability. Typically, banks provide credit to clients in one of two ways: banks can originate new loans (on the balance sheet) and provide lines of credit (off the balance sheet) (Allen, 2012).

The agency problem is another major concern that can create bank credit risk. Owing to the information asymmetry between a bank and a borrower, a borrower can fail to fulfill their commitment to a bank, which creates moral hazard. To minimize the credit risk, banks should adhere to strict underwriting standards and diversify exposures (Casu et al., 2006). In addition, in terms of the problem of adverse selection, banks can screen borrowers by assessing their ability to repay loans before issuing the credit.

\subsection{The relationship between liquidity and credit risk in banks}

A large amount of literature has been written about credit risk, starting with Merton (1974), whereas liquidity risk was a largely unexplored topic until 1998 (Imbierowicz and Rauch, 2014). Most authors explore liquidity risk and credit risk separately, but the link between the two has received only limited attention (e.g., Hertrich, 2015; Imbierowicz and Rauch, 2014). In general, these limited studies provide two arguments regarding the relationship between credit risk and liquidity risk in banks.

The first, grounded in the classic financial intermediation theory (Bryant, 1980) and the Diamond and Dybvig (1983) model, posits a positive relationship between liquidity risk and credit risk. In particular, a loan default can trigger a decrease in cash flow and depreciation in loan assets, thus increasing liquidity risk (Dermine, 1986). A new body of empirical study also supports this positive relationship. Diamond and Rajan (2001) state that if a bank provides loans to many distressed projects, it is more likely to fail to meet depositors' demands. Furthermore, if the values of those assets deteriorate, many depositors will demand a return of their funds, which will result in cash outflows. In-line with Diamond and Rajan (2001), Nikomaram et al. (2013) document a positive relationship between credit risk and liquidity risk in the Islamic banking sector. Gorton and Metrick (2011) show a different perspective on how perceived credit risk can lead to liquidity risk. Perceived credit risk (subprime loans) caused a substantial increase in refinancing rates and funding haircuts in the interbank market during the most recent financial crisis. Acharya and Viswanathan (2011) suggest that when asset prices deteriorate, it is more difficult to roll over debt because a liquidity problem exists. Based on the Diamond and Dybvig (1983) model, He and Xiong (2012) also focused on the debt rollover risk and found that lenders will not roll over debt contracts if the value of the underlying asset is below a certain threshold. In addition, Boss and Scheicher (2002) suggest a positive relationship between credit risk and liquidity risk in the European corporate bond market. Similarly, Ericsson and Renault (2006) established a bond valuation model and found that credit risk has a positive relationship with illiquidity.

However, there are other papers that provide negative or null evidence regarding the relationship between liquidity risk and credit risk (e.g., Cai and Thakor, 2008; Wagner, 2007). In general, these studies only focus on specific features of credit risk or liquidity risk, such as assets, deposits, and loan commitments, or on narrow economic circumstances. In particular, Nikomaram et al. (2013) use different proxies of liquidity risk and credit risk in their study and obtain different results regarding the relationship between the two risks, either positive or negative. Imbierowicz and Rauch (2014) failed to find a meaningful impact of credit risk on liquidity risk in US banks.

Studies with a negative or null relationship between liquidity risk and credit risk mostly focus on specific aspects of the risks given certain assumptions and economic environments. However, most recent empirical studies support the positive 
relationship between credit risk and liquidity risk, which is consistent with the classic financial intermediation theory (Bryant, 1980) and the Diamond and Dybvig (1983) model. Thus, from a broad perspective, we address the following hypothesis, H1: Credit risk is positively correlated with liquidity risk.

\section{DATA AND METHODOLOGY}

\subsection{Data and sample selection}

We build a novel sample of Ukrainian banks for the period from Q1 2009 to Q4 2015. All bank-specific information is extracted from the quarterly reports of Ukrainian banks from the website of the National Bank of Ukraine (NBU). We start with the universe of available Ukrainian banks from the NBU and remove the banks that have had their license revoked or have been liquidated during the banking sector clean-up since 2014 (banks are removed from the dataset as of their date of removal from the market). Next, only banks with financial information available for at least two consecutive quarters are retained. Finally, we drop observations with extreme and questionable values. After the filtering process, our final estimation sample consists of 176 Ukrainian banks.

\subsection{Liquidity risk and credit risk variables}

In this study, we use two main variables to measure liquidity and credit risk. Liquidity risk reflects banks' ability to deal with unexpected liquid demand. Per Cornett et al. (2011), we use liquidity position as a proxy for liquidity risk, which is calculated as the change in total liquid assets during a quarter compared with total assets at the start of a quarter. ${ }^{3}$ Total liquid assets include cash and other assets a bank can quickly convert to cash. ${ }^{4}$ In our study, the value of the liquidity risk variable can either be positive or negative. A negative value of liquidity risk means a bank has a shortage of liquidity. A lower value indicates a higher liquidity risk. On the other hand, a positive value is a sign of low liquidity risk and is a sign a bank can cover some short-term withdrawals using liquid assets.

Table 1. Definition of variables

\begin{tabular}{|l||c|}
\hline Variable name & Definition \\
\hline Liquidity risk & $\Delta$ Liquid assets $_{i, t} /$ Total assets $_{\mathrm{t}-1}$ \\
\hline Credit risk & Non-performing loans/Total loans \\
\hline Capital ratio & Total equity/Total assets \\
\hline Illiquidity & Illiquid assets/Total assets \\
\hline Efficiency ratio & Operating expenses/Total income \\
\hline Deposit ratio & Total deposit/Total assets \\
\hline Loans ratio & Loans/Total assets \\
\hline Size & Log(Total assets) \\
\hline ROA & Pre-tax profit/Total assets \\
\hline Ownership & Dummy variable: 1 for a foreign-owned bank \\
\hline
\end{tabular}

Furthermore, credit risk shows the potential a bank borrower or a counterparty fails to meet obligations in accordance with agreed terms. We follow previous studies (Gonzalez, 2005; Liang et al., 2013) and as a proxy for credit risk use the nonperforming loans (NPL) ratio - impaired loans divided by total loans. This measure captures the current risk level of a bank's loan portfolio. A higher value of the credit risk variable indicates a higher level of credit risk at a bank.

\subsection{Model specification and descriptive statistics}

To estimate the effect of credit risk on liquidity risk, we use the following model:

$$
\text { Liquidity risk }_{i, t}=\alpha+\beta \text { Credit risk }_{i, t-1}+X_{i, t-1} \delta+\theta_{t}+\mu_{i}+\varepsilon_{i, t}{ }^{\prime}
$$

where $i$ is the bank identifier and $t$ is the year. Model (1) is estimated using a fixed-effects estimator, justified using the Hausman Test. Using the fixed-effects model enables us to control for unobserved heterogeneity. In this model, liquidity risk is the

\footnotetext{
${ }^{3}$ Liquidity risk $=\Delta$ Liquid assets ${ }_{i, t} /$ total $_{\text {assets }}{ }_{i,-1}$

${ }^{4}$ Due to the availability of data, liquid assets in this study include cash balances, held-to-maturity securities, available-for-sale securities, and financial assets designated at fair value through profit or loss.
} 
dependent variable and $\alpha$ is constant. All independent variables are estimated with a one-quarter lag. The coefficient of key interest, $\beta$, captures the impact of credit risk on liquidity risk. A positive value of $\beta$ indicates a positive relationship between credit risk and liquidity risk in Ukrainian banks, while a negative value denotes a negative relationship. $\mu$ is an individual-specific effect, which varies across banks, and $\varepsilon$ denotes the error term, which varies among banks and across time periods. Additionally, the reported standard errors are adjusted for potential heteroscedasticity. However, our model (1) also has limitations. For example, it fails to address the endogeneity problem even though we use the one-quarter lagged independent variables.

Based on existing studies of bank risk (e.g., Imbierowicz and Rauch, 2014; Nikomaram et al., 2013), we include a set of control variables $\mathrm{X}_{i, t}$ that can influence bank liquidity risk, namely the illiquidity ratio, the capital ratio, the efficiency ratio, deposit ratio, loan ratio, size, return on assets (ROA), and ownership. The illiquidity ratio is the ratio of illiquid assets (assets not easily convertible to cash) to total assets. The efficiency ratio is calculated as operating expenses divided by total income, which indicates a bank's ability to turn expenses into revenue. The capital ratio, the proportion of total equity to total assets, reflects how well a bank operates and develops. In our study, deposit ratio and loan ratio are normalized by total assets to normalize differences in bank size. Size is defined as the natural logarithm of total assets. Return on assets (ROA) is measured as after-tax profit over total assets, which measures a bank's ability to generate profit with its assets. A dummy variable for foreign banks (ownership) is also included to account for ownership type; this variable equals 1 if a bank has foreign ownership and 0 if a bank is owned solely by domestic entities.

Table 2 reports the descriptive statistics for each variable in model (1). On average, credit risk is 0.123 , which implies a low quality of loans in Ukrainian banks, with a slightly elevated NPL ratio. Liquidity risk averages 0.027 and ranges from -0.402 to 0.552. This suggests Ukrainian banks in our sample have relatively low liquidity risk. The average capital ratio in Ukrainian banks is around $21 \%$ and the average illiquidity ratio is $15.8 \%$. The average efficiency ratio of 0.407 suggests Ukrainian banks are inefficient in converting assets into revenue. On average, the value of normalized deposit ratio is $32.6 \%$, while for loan ratio it is slightly higher at $56.6 \%$. In terms of operating performance, Ukrainian banks generate an average ROA of around -0.003 . Approximately $16.9 \%$ of banks have foreign ownership.

Table 2. Descriptive statistics

\begin{tabular}{|c|c|c|c|c|c|c|c|c|}
\hline Variables & Mean & Std & Min & P25 & P50 & P75 & Max & $\mathbf{N}$ \\
\hline Liquidity risk & 0.027 & 0.122 & -0.402 & -0.033 & 0.016 & 0.075 & 0.552 & 3.553 \\
\hline Credit risk & 0.123 & 0.142 & 0.000 & 0.033 & 0.080 & 0.154 & 0.971 & 3.827 \\
\hline Illiquid ratio & 0.158 & 0.132 & 0.004 & 0.056 & 0.118 & 0.224 & 0.684 & 3.773 \\
\hline Efficiency ratio & 0.407 & 0.248 & 0.050 & 0.249 & 0.346 & 0.507 & 2.009 & 3.707 \\
\hline Deposit ratio & 0.326 & 0.161 & 0.000 & 0.206 & 0.335 & 0.444 & 0.727 & 3.784 \\
\hline Loan ratio & 0.566 & 0.176 & 0.055 & 0.452 & 0.583 & 0.697 & 0.923 & 3.786 \\
\hline Size & 14.358 & 1.571 & 11.501 & 13.132 & 14.165 & 15.308 & 18.982 & 3.752 \\
\hline Capital ratio & 0.210 & 0.157 & 0.000 & 0.104 & 0.156 & 0.259 & 0.834 & 3.797 \\
\hline ROA & -0.003 & 0.022 & -0.313 & -0.000 & 0.000 & 0.001 & 0.035 & 3.782 \\
\hline Ownership & 0.169 & 0.375 & 0.000 & 0.000 & 0.000 & 0.000 & 1.000 & 3.505 \\
\hline
\end{tabular}

Note. This table provides summary statistics for the main variable in our study.

Multicollinearity is an important issue in regression models; it occurs when two or more variables are highly correlated. When variable ranges are narrow, a model's specifications can cause multicollinearity. Multicollinearity can also be the result of an over-determined model, which includes models with small numbers of observations but significant numbers of variables. The correlation matrix between the main variables is shown in Table 3. The results show there is no multicollinearity in our main model. 
Table 3. Correlation matrix between variables

\begin{tabular}{|c|c|c|c|c|c|c|c|c|c|c|}
\hline & $\begin{array}{l}\text { Liquidity } \\
\text { risk }\end{array}$ & $\begin{array}{l}\text { Credit } \\
\text { risk }\end{array}$ & $\begin{array}{l}\text { Illiquid } \\
\text { ratio }\end{array}$ & $\begin{array}{l}\text { Efficiency } \\
\text { ratio }\end{array}$ & $\begin{array}{l}\text { Deposit } \\
\text { ratio }\end{array}$ & $\begin{array}{l}\text { Loan } \\
\text { ratio }\end{array}$ & Size & $\begin{array}{l}\text { Capital } \\
\text { ratio }\end{array}$ & ROA & $\begin{array}{l}\text { Owner- } \\
\text { ship }\end{array}$ \\
\hline Liquidity risk & 1.000 & & & & & & & & & \\
\hline Credit risk & $-0.110^{* * *}$ & 1.000 & & & & & & & & \\
\hline Illiquid ratio & $-0.036^{* * *}$ & $0.140^{* * *}$ & 1.000 & & & & & & & \\
\hline Efficiency ratio & $-0.079^{* * *}$ & $0.215^{* * *}$ & $0.088^{* * *}$ & 1.000 & & & & & & \\
\hline Deposit ratio & $0.063^{* * *}$ & $-0.086^{* * *}$ & $-0.105^{* * *}$ & $-0.148^{* * *}$ & 1.000 & & & & & \\
\hline Loan ratio & $-0.035^{* *}$ & $-0.210^{* * *}$ & $-0.507^{* * *}$ & $-0.258^{* * *}$ & $0.201^{* * *}$ & 1.000 & & & & \\
\hline Size & -0.003 & $0.202^{* * *}$ & $0.196^{* * *}$ & $-0.192^{* * *}$ & 0.015 & $0.037^{* *}$ & 1.000 & & & \\
\hline Capital ratio & $-0.074^{* * *}$ & $-0.113^{* * *}$ & $-0.143^{* * *}$ & $0.235^{* * *}$ & $-0.410^{* * *}$ & 0.010 & $-0.613^{* * *}$ & 1.000 & & \\
\hline ROA & $0.145^{* * *}$ & $-0.190^{* * *}$ & -0.013 & $-0.049^{* * *}$ & -0.022 & $-0.030^{*}$ & $-0.057^{* * *}$ & $0.070^{* * *}$ & 1.000 & \\
\hline Ownership & $-0.042^{* *}$ & $0.120^{* * *}$ & $-0.056^{* * *}$ & $0.090^{* * *}$ & $-0.187^{* * *}$ & $0.081^{* * *}$ & $0.435^{* * *}$ & $-0.215^{* * *}$ & -0.018 & 1.000 \\
\hline
\end{tabular}

Note: This table shows the correlation between each variable.

\section{EMPIRICAL RESULTS}

\subsection{The relationship between liquidity risk and credit risk}

Table 4 reports the basic results of the relationship between credit risk and liquidity risk in Ukrainian banks. The coefficient of credit risk is negative and significant at $10 \%$, which supports our hypothesis (H1). Since a lower value of liquidity indicates a higher liquidity risk, our results suggest that higher credit risk leads to higher liquidity risk in Ukrainian banks. More specifically, when credit risk increases by $1 \mathrm{pp}$, liquidity drops by $0.072 \mathrm{pp}$.

Similar to Cornett et al. (2001) and Imbierowicz and Rauch (2014), our results provide additional evidence to support the classic financial intermediation theory (Bryant, 1980) and the Diamond and Dybvig (1983) model. As a financial channel between depositors and borrowers, banks allocate deposits and provide loans. Typically, banks maximize profits by increasing the interest spread between deposits and loans. Since liquidity risk is the cost of profit-lowering, a loan default is more likely to lower cash flow and trigger depreciations in loan assets, which can ultimately result in an increase in liquidity risk (Dermine, 1986). Additionally, if a bank issues loans to many distressed projects, depositors can lose confidence in the bank and demand the return of their funds. In the event the bank is unable to meet those depositors' needs, liquidity shortages occur.

With respect to other bank-specific characteristics, the illiquidity ratio has a positive effect on liquidity at a significance level of $1 \%$. This is consistent with Cornett et al. (2011), who studied the US banking sector. This indicates that banks with a higher fraction of illiquid assets in the investment portfolio tend to increase the holding of liquid assets. The efficiency ratio shows a negative relationship with liquidity risk, but it is not statistically significant. Deposit ratio and loan ratio both have a negative relationship with liquidity risk. More specifically, a $1 \mathrm{pp}$ increase in deposit ratio and loan ratio results in a increase of 0.083 $\mathrm{pp}$ and $0.070 \mathrm{pp}$ in liquidity risk, respectively. Similarly, the capital ratio coefficient is also positive, which suggests a negative relationship with liquidity risk. By contrast, the size coefficient is negative, which indicates a positive impact on liquidity risk. Specifically, a $1 \mathrm{pp}$ increase in bank size decreases liquidity by $0.068 \mathrm{pp}$. 
Table 4. Relationship between liquidity risk and credit risk

\begin{tabular}{|c|c|}
\hline & Liquidity risk \\
\hline \multirow[t]{2}{*}{ Credit risk } & $-0.072^{* *}$ \\
\hline & $(0.028)$ \\
\hline \multirow[t]{2}{*}{ Illiquid ratio } & $0.154^{* * *}$ \\
\hline & $(0.040)$ \\
\hline \multirow[t]{2}{*}{ Efficiency ratio } & -0.022 \\
\hline & $(0.015)$ \\
\hline \multirow[t]{2}{*}{ Deposit ratio } & $0.083^{* *}$ \\
\hline & (0.037) \\
\hline \multirow[t]{2}{*}{ Loan ratio } & $0.070^{* *}$ \\
\hline & $(0.035)$ \\
\hline \multirow[t]{2}{*}{ Size } & $-0.068^{* * *}$ \\
\hline & $(0.010)$ \\
\hline \multirow[t]{2}{*}{ Capital ratio } & $0.117^{* *}$ \\
\hline & $(0.048)$ \\
\hline \multirow[t]{2}{*}{ ROA } & $0.387^{* *}$ \\
\hline & $(0.183)$ \\
\hline Quarter dummy & Yes \\
\hline $\mathrm{N}$ & 3,306 \\
\hline $\mathrm{R}^{2}$ & 0.180 \\
\hline
\end{tabular}

Note: This table shows the relationship between credit risk and liquidity risk. Liquidity risk is calculated as the change in liquid assets divided by total assets in the previous quarter. Credit risk is measured as nonperforming loans divided by total loans. The capital ratio is total equity divided by total assets. The illiquidity ratio is defined as the ratio of illiquid assets to total assets. The efficiency ratio is calculated as operating expenses divided by total income. Deposit ratio and Loan ratio are both normalized by total assets. ROA is measured as pre-tax profit divided by total assets. Size is the log of total assets. Ownership is a dummy variable that is equal to 1 for a foreign-owned bank and 0 for a domestic-owned bank. The analysis uses the panel fixed-effect estimator with lagged independent variables. A constant is included in the estimation but not reported. The robust error of each coefficient is shown in parentheses. ${ }^{*},{ }^{* *},{ }^{* * *}$ indicate the statistical significance level at $10 \%, 5 \%$, and $1 \%$, respectively.

\subsection{Results for foreign and domestic banks}

From the previous study, we see that credit risk is positively correlated with liquidity risk. To further investigate the link, we explore whether banks of different characteristics behave differently in terms of risk. In Ukraine, nearly $20 \%$ of banks have foreign ownership. To differentiate the difference between domestic and foreign banks in terms of the behavior on risk, we categorize all Ukrainian banks into two groups: foreign-owned banks and domestically owned banks. Table 5 shows the results of the relationship between credit risk and liquidity risk by ownership group. The credit risk coefficient is negative and significant in columns (1) and (2), which suggests credit risk is positively correlated with liquidity risk in foreign- and domestic-owned banks. However, the positive correlation is more pronounced in foreign banks. In foreign-owned banks, when credit risk rises by $1 \mathrm{pp}$, liquidity falls by $0.116 \mathrm{pp}$. In domestically owned banks, a $1 \mathrm{pp}$ increase in credit risk leads to a $0.061 \mathrm{pp}$ decrease in liquidity. Based on the global advantage hypothesis, foreign banks benefit from competitive advantages relative to domestic banks, such as better risk management and advanced information technologies. Accordingly, foreign banks could have lower level of risk than domestic banks. Our results, however, suggest that the positive relationship between credit risk and liquidity risk is more pronounced in foreign banks, which is counterintuitive. Therefore, it might be because domestically owned banks typically underestimate risks in Ukrainian banks. Additionally, in-line with our baseline results, the illiquidity ratio is negatively correlated with liquidity risk at a $10 \%$ significance level in domestically owned banks. By contrast, size has a positive relationship with liquidity risk in both foreign- and domestic-owned banks. The influence is more pronounced in domestic banks. Fur- 
thermore, for foreign banks, deposit ratio have a negative effect on liquidity risk, while ROA is negatively correlated with bank liquidity risk only in domestic banks.

\section{Table 5. The relationship between credit risk and liquidity risk by bank ownership}

\begin{tabular}{|c|c|c|}
\hline & Foreign banks & Domestic banks \\
\hline & (1) & (2) \\
\hline \multirow[t]{2}{*}{ Credit risk } & $-0.116^{* *}$ & $-0.061^{*}$ \\
\hline & $(0.044)$ & $(0.036)$ \\
\hline \multirow[t]{2}{*}{ Illiquid ratio } & 0.093 & $0.174^{* * *}$ \\
\hline & $(0.072)$ & $(0.050)$ \\
\hline \multirow[t]{2}{*}{ Efficiency ratio } & -0.022 & -0.019 \\
\hline & $(0.022)$ & (0.019) \\
\hline \multirow[t]{2}{*}{ Deposit ratio } & $0.165^{* *}$ & 0.064 \\
\hline & $(0.062)$ & $(0.044)$ \\
\hline \multirow[t]{2}{*}{ Loan ratio } & 0.064 & 0.062 \\
\hline & $(0.065)$ & $(0.043)$ \\
\hline \multirow[t]{2}{*}{ Size } & $-0.055^{* *}$ & $-0.077^{* * *}$ \\
\hline & $(0.024)$ & $(0.012)$ \\
\hline \multirow[t]{2}{*}{ Capital ratio } & 0.235 & 0.081 \\
\hline & $(0.143)$ & $(0.054)$ \\
\hline \multirow[t]{2}{*}{ ROA } & -0.040 & $0.373^{*}$ \\
\hline & $(0.287)$ & $(0.208)$ \\
\hline Quarter dummy & Yes & Yes \\
\hline$N$ & 530 & 2,494 \\
\hline $\mathrm{R}^{2}$ & 0.393 & 0.171 \\
\hline
\end{tabular}

Note: This table shows the relationship between credit risk and liquidity risk. Column (1) reports the results for foreign-owned banks and column (2) for domestic banks. Liquidity risk is calculated as the change in liquid assets divided by total assets in the previous quarter. Credit risk is measured as non-performing loans divided by total loans. The capital ratio is total equity divided by total assets. The illiquidity ratio is defined as the ratio of illiquid assets to total assets. The efficiency ratio is calculated as operating expenses divided by total income. Deposit ratio and Loan ratio are both normalized by total assets. ROA is measured as pre-tax profit divided by total assets. Size is the log of total assets. Ownership is a dummy variable that is equal to 1 for a foreign-owned bank and 0 for a domestic-owned bank. The analysis uses the panel fixed-effect estimator with lagged independent variables. A constant is included in the estimation but not reported. The robust error of each coefficient is shown in parentheses. ${ }^{*},{ }^{* *},{ }^{* * *}$ indicate the statistical significance level at $10 \%, 5 \%$, and $1 \%$, respectively.

\subsection{Results for large and small banks}

Ukraine's banking sector has a lower concentration and is more fragmented than other transition countries, with the prevalence of small "pocket banks" that often lend to related parties. In this section, to distinguish the effect of credit risk on liquidity risk in different sizes of banks, banks are divided into large and small sub-groups based on total assets. The median total asset size across the sector (UAH 1,166,286,000) is the threshold: large banks have above-median total assets and small banks have below-median total assets. In Table 6, we find that in large banks, credit risk shows a positive relationship with liquidity risk, with a $1 \%$ significance level. A 1 pp increase in credit risk results in an 0.085 pp decrease in liquidity. At small banks, credit risk has no effect on liquidity risk.

In terms of other variables, the illiquidity ratio and loan ratio in both small and large Ukrainian banks are negatively correlated with liquidity risk at a $1 \%$ significance level. Similar to previous baseline results, size has a positive influence on liquidity 
risk in both small and large banks, but the impact is greater in small banks. ROA is negatively correlated with liquidity risk in small banks, while the efficiency ratio has a positive relationship with liquidity risk in large banks.

\section{Table 6. The relationship between credit risk and liquidity risk by bank size}

\begin{tabular}{|c|c|c|}
\hline & Small banks & Large banks \\
\hline & (1) & (2) \\
\hline \multirow[t]{2}{*}{ Credit risk } & 0.005 & $-0.085^{* * *}$ \\
\hline & (0.059) & (0.029) \\
\hline \multirow[t]{2}{*}{ Illiquid ratio } & $0.183^{* *}$ & $0.166^{* * *}$ \\
\hline & $(0.072)$ & $(0.060)$ \\
\hline \multirow[t]{2}{*}{ Efficiency ratio } & 0.025 & $-0.061^{* * *}$ \\
\hline & $(0.024)$ & $(0.018)$ \\
\hline \multirow[t]{2}{*}{ Deposit ratio } & 0.090 & 0.070 \\
\hline & $(0.063)$ & $(0.057)$ \\
\hline \multirow[t]{2}{*}{ Loan ratio } & $0.091^{*}$ & $0.095^{*}$ \\
\hline & $(0.052)$ & (0.054) \\
\hline \multirow[t]{2}{*}{ Size } & $-0.122^{* * *}$ & $-0.083^{* * *}$ \\
\hline & $(0.023)$ & $(0.016)$ \\
\hline \multirow[t]{2}{*}{ Capital ratio } & 0.040 & 0.129 \\
\hline & $(0.072)$ & (0.102) \\
\hline \multirow[t]{2}{*}{ ROA } & $1.082^{* * *}$ & 0.121 \\
\hline & $(0.327)$ & $(0.170)$ \\
\hline Quarter dummy & Yes & Yes \\
\hline $\mathrm{N}$ & 1,605 & 1,701 \\
\hline $\mathrm{R}^{2}$ & 0.148 & 0.291 \\
\hline
\end{tabular}

Note: This table shows the relationship between credit risk and liquidity risk. Column (1) reports the results for small banks and column (2) for large banks. Liquidity risk is calculated as the change in liquid assets divided by total assets in the previous quarter. Credit risk is measured as non-performing loans divided by total loans. The capital ratio is total equity divided by total assets. The illiquidity ratio is defined as the ratio of illiquid assets to total assets. The efficiency ratio is calculated as operating expenses divided by total income. Deposit ratio and Loan ratio are both normalized by total assets. ROA is measured as pre-tax profit divided by total assets. Size is the log of total assets. Ownership is a dummy variable that is equal to 1 for a foreign-owned bank and 0 for a domestic-owned bank. The analysis uses the panel fixed-effect estimator with lagged independent variables. A constant is included in the estimation but not reported. The robust error of each coefficient is shown in parentheses. ${ }^{*},{ }^{* *},{ }^{* * *}$ indicate the statistical significance level at $10 \%, 5 \%$, and $1 \%$, respectively.

\section{ROBUSTNESS TEST}

\subsection{Alternative measures}

In addition to our previous analysis, we estimate the relationship between liquidity risk and credit risk using an alternative measure of credit risk. In this section, following Liang et al. (2013), we recalculate credit risk as the ratio of non-performing loans (NPLs) to total assets. As shown in Table 7, the alternative measure of credit risk still has a positive relationship with liquidity risk. Specifically, if credit risk increases by $1 \mathrm{pp}$, liquidity reduces by $0.160 \mathrm{pp}$. This result is consistent with our previous analysis and provides additional evidence for our hypothesis $(\mathrm{H} 1)$ : higher credit risk at banks leads to higher liquidity risk. 
As in Table 4 (main model), most of the control variables have a significant influence on liquidity risk. Overall, size is negatively correlated to liquidity risk. By contrast, the illiquidity ratio, the capital ratio, loan ratio, and deposit ratio are positively related to liquidity risk in Ukrainian banks.

\section{Table 7. The relationship between credit risk and liquidity risk (robust)}

\begin{tabular}{|c|c|}
\hline & Liquidity risk \\
\hline \multirow[t]{2}{*}{ Credit risk } & $-0.160^{* * *}$ \\
\hline & $(0.060)$ \\
\hline \multirow[t]{2}{*}{ Illiquid ratio } & $0.154^{* * *}$ \\
\hline & $(0.040)$ \\
\hline \multirow[t]{2}{*}{ Efficiency ratio } & -0.021 \\
\hline & $(0.015)$ \\
\hline \multirow[t]{2}{*}{ Deposit ratio } & $0.084^{* *}$ \\
\hline & (0.037) \\
\hline \multirow[t]{2}{*}{ Loan ratio } & $0.090^{* * *}$ \\
\hline & (0.034) \\
\hline \multirow[t]{2}{*}{ Size } & $-0.069^{* * *}$ \\
\hline & (0.010) \\
\hline \multirow[t]{2}{*}{ Capital ratio } & $0.119^{* *}$ \\
\hline & (0.047) \\
\hline \multirow[t]{2}{*}{ ROA } & $0.357^{*}$ \\
\hline & $(0.183)$ \\
\hline Quarter dummy & Yes \\
\hline $\mathrm{N}$ & 3,306 \\
\hline $\mathrm{R}^{2}$ & 0.181 \\
\hline
\end{tabular}

Note: This table shows the relationship between credit risk and liquidity risk. Liquidity risk is calculated as the change in liquid assets divided by total assets in the previous quarter. Credit risk is measured as nonperforming loans divided by total loans. The capital ratio is total equity divided by total assets. The illiquidity ratio is defined as the ratio of illiquid assets to total assets. The efficiency ratio is calculated as operating expenses divided by total income. Deposit ratio and Loan ratio are both normalized by total assets. ROA is measured as pre-tax profit divided by total assets. Size is the log of total assets. Ownership is a dummy variable that is equal to 1 for a foreign-owned bank and 0 for a domestic-owned bank. The analysis uses the panel fixed-effect estimator with lagged independent variables. A constant is included in the estimation but not reported. The robust error of each coefficient is shown in parentheses. ${ }^{*},{ }^{* *},{ }^{* * *}$ indicate the statistical significance level at $10 \%, 5 \%$, and $1 \%$, respectively.

\subsection{Potential endogeneity concern}

Endogeneity is one area of concern in our analysis. The relationship between credit risk and liquidity risk may be biased because of a possible correlation between the independent variables and the error term. On one hand, banks with high level of non-performing loans may carry liquidity risk. On the other, banks with liquidity shortages may also face credit risk. In the previous analysis, we partially address this reverse causality by employing a one-quarter lagged credit risk.

As a possible solution, our empirical analysis is extended to use the Arellano-Bond (1991) dynamic Generalized Method of Moments (GMM) estimator, which accounts for unobserved heterogeneity as well as the dynamic relation between credit risk and previous liquidity risk. We report the GMM regressions in Table 8. 
Table 8. The relationship between credit risk and liquidity risk (GMM)

\begin{tabular}{|c|c|}
\hline & Liquidity risk \\
\hline \multirow[t]{2}{*}{ L. Liquidity } & $-0.065^{* *}$ \\
\hline & $(0.033)$ \\
\hline \multirow[t]{2}{*}{ Credit risk } & 0.171 \\
\hline & (0.108) \\
\hline \multirow[t]{2}{*}{ Illiquid ratio } & -0.022 \\
\hline & (0.119) \\
\hline \multirow[t]{2}{*}{ Efficiency ratio } & $-0.240 * * *$ \\
\hline & $(0.078)$ \\
\hline \multirow[t]{2}{*}{ Deposit ratio } & $0.183 * *$ \\
\hline & $(0.078)$ \\
\hline \multirow[t]{2}{*}{ Loan ratio } & -0.024 \\
\hline & $(0.086)$ \\
\hline \multirow[t]{2}{*}{ Size } & $-0.057 * * *$ \\
\hline & $(0.021)$ \\
\hline \multirow[t]{2}{*}{ Capital ratio } & 0.049 \\
\hline & $(0.132)$ \\
\hline \multirow[t]{2}{*}{ ROA } & $1.581 * * *$ \\
\hline & $(0.497)$ \\
\hline Quarter dummies & Yes \\
\hline $\mathrm{N}$ & 3,001 \\
\hline AR(2) P-value & 0.740 \\
\hline Hansen Test P-value & 0.184 \\
\hline
\end{tabular}

Note: This table shows the results of the GMM regression of the relationship between credit risk and liquidity risk. Liquidity risk is calculated as the change in liquid assets divided by total assets in the previous quarter. Credit risk is measured as non-performing loans divided by total loans. The capital ratio is total equity divided by total assets. The illiquidity ratio is defined as the ratio of illiquid assets to total assets. The efficiency ratio is calculated as operating expenses divided by total income. Deposit ratio and Loan ratio are both normalized by total assets. ROA is measured as pre-tax profit divided by total assets. Size is the log of total assets. Ownership is a dummy variable that is equal to 1 for a foreign-owned bank and 0 for a domestic-owned bank. The analysis uses the panel fixed-effect estimator with lagged independent variables. A constant is included in the estimation but not reported. The robust error of each coefficient is shown in parentheses. ${ }^{*},{ }^{* *},{ }^{* * *}$ indicate the statistical significance level at $10 \%, 5 \%$, and $1 \%$, respectively.

All the independent variables are assumed to be endogenous variables, except the quarter dummies. The lags (t-2 and $t-3)$ of liquidity and lags ( $\mathrm{t}-2, \mathrm{t}-3$, and $\mathrm{t}-4)$ of the endogenous variables, together with all the lags of the exogenous variables, are instrument variables. In Table 8, our instruments satisfy the second order serial correlation test and the Hansen Test of overidentification. However, we fail to find a negative and significant impact of credit risk on liquidity risk.

\section{CONCLUSION}

Credit risk and liquidity risk are major sources of bank default risk. The existing literature focuses largely on the effect of credit risk or liquidity risk in the banking sector separately, while limited studies consider the link between the two. We expand the literature by investigating the relationship between credit risk and liquidity risk, as well as the effect of banks' character- 
istics on the link between credit risk and liquidity risk in an emerging economy, Ukraine. This paper utilizes a novel sample of Ukrainian banks, covering 176 banks over the period from Q1 2009 to Q4 2015. We find that the credit and liquidity risk in Ukraine's banking sector is relatively high compared to other developed economy banking sectors.

Our results provide empirical evidence to support the classic financial intermediation theory (Bryant, 1980) and the Diamond and Dybvig (1983) model. In particular, higher credit risk leads to higher liquidity risk. Banks maximize profit by increasing the interest spread between deposits and loans. Then, a loan default leads to lower cash flow and triggers depreciations in loan assets, which ultimately increases liquidity risk in banks.

Since banks with different characteristics behave differently in terms of risk, we then further estimate the effect of bank size and ownership on the positive link between credit risk and liquidity risk. Our findings suggest that the positive relationship is slightly stronger in larger banks and foreign-owned banks. We conduct a robustness check by replacing credit risk with an alternative measure, which yields consistent results.

Our empirical findings carry some implications for regulators and policy makers. Managing credit risk and liquidity risk is important in the banking sector, and risk management practices can affect banking sector stability. Given Ukraine's unstable financial system, more efforts should be placed on the management of liquidity risk and credit risk in conjunction with asset quality.

\section{References}

- Acharya V., Viswanathan S. (2011). Leverage, moral hazard, and liquidity. Journal of Finance, Vol. 66, No. No. 1, pp. 99-138.

- Allen F. (2012). The global macro economy and finance. Basingstoke: Palgrave Macmillan.

- Barisitz S., Fungáčová Z. (2015). Ukraine: struggling banking sector and substantial political and economic uncertainty. Bank of Finland, Helsinki, pp. 1-24.

- Barisitz S., Gunter U., Lahnsteiner M. (2012). Ukrainian banks face heightened uncertainty and challenges. Financial Stability Report, No. 23, Vol. 6, pp. 50-57.

- Barisitz S., Lahnsteiner M. (2009). Investor Commitment Tested by Deep Crisis: Banking Development in Ukraine. Financial Stability Report, No. 18, pp.69-77.

- Basel Committee on Banking Supervision, BCBS (2000). Principles for the Management of Credit Risk. Available at: http://www.bis.org/publ/bcbs75.pdf

- Basel Committee on Banking Supervision, BCBS (2008). Principles for sound liquidity risk management and supervision. Available at: http://www.bis.org/publ/bcbs144.pdf

- Berger A., Bouwman C. (2009). Bank Liquidity Creation. Review of Financial Studies, Vol. 22, No. 9, pp. 3779-3837.

- Berger A., Bouwman C. (2013). How does capital affect bank performance during financial crises? Journal of Financial Economics, Vol. 109, No. 1, pp. 146-176.

- Bhattacharya S., Thakor A. (1993). Contemporary Banking Theory. Journal of Financial Intermediation, Vol. 3, No. 1, pp. $2-50$.

- Boss M., Scheicher M. (2002). The determinants of credit spread changes in the euro area. Bank for International Settlements Papers, Vol. 12, No. 2, pp. 181-199.

- Bryant J. (1980). A model of reserves, bank runs, and deposit insurance. Journal of Banking \& Finance, Vol. 4, No. 4, pp. 335-344.

- Cai J., Thakor A. (2008). Liquidity Risk, Credit Risk and Interbank Competition. SSRN Electronic Journal.

- Castro V. (2013). Macroeconomic determinants of the credit risk in the banking system: The case of the GIPSI. Economic Modelling, Vol. 31, pp. 672-683.

- Casu B., Girardone C., Molyneux P. (2006). Introduction to Banking. Essex: Pearson Education Limited.

- Cornett M., McNutt J., Strahan P., Tehranian H. (2011). Liquidity risk management and credit supply in the financial crisis. Journal of Financial Economics, Vol. 101, No. 2, pp. 297-312. 
- Dermine J. (1986). Deposit rates, credit rates and bank capital: The Klein-Monti Model Revisited. Journal of Banking \& Finance, Vol. 10, No. 1, pp. 99-114.

- DeYoung R., Jang K.Y. (2016). Do banks actively manage their liquidity? Journal of Banking \& Finance, Vol. 66, No. 5, pp. 143-161.

- Diamond D., Dybvig P. (1983). Bank Runs, Deposit Insurance, and Liquidity. Journal of Political Economy, Vol. 91, No. 3, pp. 401-419.

- Diamond D., Rajan R. (2001). Liquidity Risk, Liquidity Creation, and Financial Fragility: A Theory of Banking. Journal of Political Economy, Vol. 109, No. 2, pp. 287-327.

- Ericsson J., Renault O. (2006). Liquidity and Credit Risk. Journal of Finance, Vol. 61, No. 5, pp. 2219-2250.

- Foos D., Norden L., Weber M. (2010). Loan growth and riskiness of banks. Journal of Banking \& Finance, Vol. 34, No. 12, pp. 2929-2940.

- Gonzalez F. (2005). Bank regulation and risk-taking incentives: An international comparison of bank risk. Journal of Banking \& Finance, Vol. 29, No. 5, pp. 1153-1184.

- Gorton G., Metrick A. (2011). Securitized Banking and the Run on Repo. Journal of Financial Economics, Vol. 104, No. 3, pp. 425-451.

- Gorton G., Winton A. (2000). Liquidity Provision, Bank Capital, and the Macroeconomy. SSRN Electronic Journal.

- Greenbaum S., Thakor A. (1995). Contemporary Financial Intermediation. Mason, Ohio: South-Western/Thomson Learning.

- He Z., Xiong W. (2012). Dynamic Debt Runs. Review of Financial Studies, Vol. 25, No. 6, pp. 1799-1843.

- Hertrich M. (2015). Does Credit Risk Impact Liquidity Risk? Evidence from Credit Default Swap Markets. International Journal of Applied Economics, Vol. 12, No. 2, pp. 1-46.

- Houston J.F., Lin C., Lin P., Ma Y. (2010). Creditor rights, information sharing, and bank risk taking. Journal of Financial Economics, Vol. 96, No. 3, pp. 485-512.

- Imbierowicz B., Rauch C. (2014). The relationship between liquidity risk and credit risk in banks. Journal of Banking \& Finance, Vol. 40, No. 12, pp. 242-256.

- Liubkina O., Borovikova M. (2013). Imbalances in the financial system of Ukraine and their transmission to the systematic risks in the monetary stability. Bulletin of Taras Shevchenko National University of Kyiv. Economics, No. 152, pp. 57-63.

- National Bank of Ukraine, NBU (2016). Financial Stability Report. Available at: https://bank.gov.ua/doccatalog/ document?id $=44001454$

- Nikomaram H., Taghavi M., Khalili Diman S. (2013). The relationship between liquidity risk and credit risk in Islamic banking industry of Iran. Management Science Letters, Vol. 3, No. 4, pp. 1223-1232.

- Roy A.D. (1952). Safety First and the Holding of Assets. Econometrica, Vol. 20, No. 3, pp. 431-449.

- Wagner W. (2007). The liquidity of bank assets and banking stability. Journal of Banking \& Finance, Vol. 31, No. 1, pp. $121-139$. 